\title{
The Canady Helios Cold Plasma Scalpel Significantly Decreases Viability in Malignant Solid Tumor Cells in a Dose-Dependent Manner
}

\author{
Warren Rowe ${ }^{1,+} \mathbb{D}$, Xiaoqian Cheng ${ }^{1,+}$, Lawan Ly ${ }^{1}$, Taisen Zhuang ${ }^{2}$, Giacomo Basadonna ${ }^{1,3}$, \\ Barry Trink ${ }^{1,4}$, Michael Keidar ${ }^{1,4}$ and Jerome Canady ${ }^{1,4, *}$ \\ 1 Jerome Canady Research Institute for Advanced Biological and Technological Sciences, \\ Takoma Park, MD 20912, USA; drwrowe@usmedinnov.com (W.R.); xcheng@usmedinnov.com (X.C.); \\ llawan@usmedinnov.com (L.L.); Giacomo.basadonna@umassmed.edu (G.B.); barrytrink@gmail.com (B.T.); \\ keidar@gwu.edu (M.K.) \\ 2 Plasma Medicine Life Sciences, Takoma Park, MD 20912, USA; tzhuang@usmedinnov.com \\ 3 Department of Surgery, University of Massachusetts School of Medicine, Worcester, MA 01655, USA \\ 4 School of Engineering \& Applied Science, The George Washington University, Washington, DC 20052, USA \\ * Correspondence: drjcanady@usmedinnov.com; Tel.: +301-270-0147 \\ + The authors contributed equally to this work.
}

Received: 19 July 2018; Accepted: 24 August 2018; Published: 7 September 2018

\begin{abstract}
To determine appropriate treatment doses of cold atmospheric plasma (CAP), the Canady Helios Cold Plasma Scalpel was tested across numerous cancer cell types including renal adenocarcinoma, colorectal carcinoma, pancreatic adenocarcinoma, ovarian adenocarcinoma, and esophageal adenocarcinoma. Various CAP doses were tested consisting of both high $(3 \mathrm{~L} / \mathrm{min})$ and low $(1 \mathrm{~L} / \mathrm{min})$ helium flow rates, several power settings, and a range of treatment times up to $5 \mathrm{~min}$. The impact of cold plasma on the reduction of viability was consistently dose-dependent; however, the anti-cancer capability varied significantly between cell lines. While the lowest effective dose varied from cell line to cell line, in each case an $80-99 \%$ reduction in viability was achievable $48 \mathrm{~h}$ after CAP treatment. Therefore, it is critical to select the appropriate CAP dose necessary for treating a specific cancer cell type.
\end{abstract}

Keywords: cold atmospheric plasma; CAP; cancer therapy; dose-dependent; renal adenocarcinoma; colorectal carcinoma; pancreatic adenocarcinoma; ovarian adenocarcinoma; esophageal adenocarcinoma

\section{Introduction}

Malignant solid tumors are characterized by high recurrence rates and low five-year survival rates. Stage IV renal adenocarcinoma presents an extremely low five-year survival rate of 0-10\% [1], while the recurrence rate may be as high as $23 \%$ [2]. While the recurrence rate of colorectal carcinoma is similar to that of renal adenocarcinoma at $19.4 \%$ to $21.6 \%$, the five-year survival rate is significantly higher at $88.6 \%$ to $89.4 \%$ [3]. Pancreatic ductal adenocarcinoma has an extremely low survival rate of $10 \%$ to $28 \%$ [4] after one year due to a very high recurrence rate of $65.5 \%$ [5]. The resulting 5-year survival rate is dismal at $6 \%$ in the United States and Europe [6]. Serous epithelial ovarian carcinoma has a very low five-year survival rate of $42 \%$ for stage III and $26 \%$ for stage IV [7] with a $19 \%$ recurrence rate [8]. Esophageal adenocarcinoma represents a similarly low five-year survival rate of $33 \%$ to $44 \%$ [9], depending on the treatment used, and can result in a recurrence rate as high as 43.2\% [10]. 
The unfortunately common recurrence of malignant solid tumors represents a unique opportunity for cold atmospheric plasma (CAP) treatment. CAP is an emerging technology that uses ionized gas to produce a plasma beam which has numerous applications in various fields, including dentistry, wound healing, surface decontamination, viral inhibition, and cancer treatment [11-16]. CAP can be used to treat the margins following tumor removal, and in doing so has the potential to remove residual cancer cells and prevent recurrence. An important step to make this a reality is to determine the correct dose of CAP to significantly reduce tumor cell viability. It has been reported that various cell lines react differently to CAP treatment [17-20]. Yan et al. studied the reactive species consumption speed of glioblastoma U87 and breast cancers MDA-MB-231 and MCF-7, and discovered that the cancer cells that could absorb or eliminate the effective species in the media faster (glioblastoma) were more resistant to plasma-activated media than both breast cancers [17]. Their results also demonstrate a wide range of effects on cell viability depending on cell type and treatment time [20]. Naciri et al. also reported that plasma sensitivity closely correlates with proliferation rates by measuring ATP levels of three cancer cell types including Chinese hamster ovary cells, osteoblast, and colon adenocarcinoma [18]. By testing eight cancerous cell lines, Ma et al. claimed that p53-deficient cancer cells are more sensitive to CAP treatment due to the lack of p53-dependent cell cycle delay at G1 [19]. Therefore, the combinations of power settings and treatment times are critical to establish the correct dosage of cell line-dependent CAP treatment.

The mechanism of the anti-cancer capacity of CAP has been increasingly understood. Several theories have been proposed, including a decrease of cell adhesion [21,22], interruption of the cell cycle [23-25], induction of apoptosis [26-29], and DNA fragmentation [30]. However, it is not yet clear whether CAP-generated reactive species are crucial for apoptosis and its associated DNA strand break or whether plasma-induced direct DNA damage provokes cell cycle checkpoint signaling that leads to apoptosis [31].

The Canady Cold Plasma Conversion Unit is unique in that it utilizes a high voltage transformer to up-convert the voltage $(1.5-50 \mathrm{kV})$, down-convert the frequency $(<300 \mathrm{kHz})$, and down-convert the power $(<30 \mathrm{~W})$ of the high-voltage output from an electrosurgical unit (U.S. Patent No. 9,999,462) [32]. We tested the Canady Helios Cold Plasma Device on a wide range of cell lines with different combinations of power settings, treatment times, and gas flow rates. With optimal dosage for each cancer type, this study provides a starting point for future animal studies and clinical trials.

\section{Materials and Methods}

\subsection{Cold Plasma Device}

All experiments were performed at the Jerome Canady Research Institute for Advanced Biological and Technological Sciences, in Takoma Park, MD, USA. Cold atmospheric plasma (CAP) was generated using a USMI SS-601 MCa high-frequency electrosurgical generator (USMI, Takoma Park, MD, USA) integrated with a USMI Cold Plasma Conversion Unit and connected to a Canady Helios Cold Plasma Scalpel. Helium flow was set to a constant $1 \mathrm{~L} / \mathrm{min}$ and $20 \mathrm{P}$ or $40 \mathrm{P}$ or $3 \mathrm{~L} / \mathrm{min}$ and power set to $40 \mathrm{P}$, $60 \mathrm{P}$, or $80 \mathrm{P}$. The plasma scalpel was placed so that the tip of the scalpel was $1.5 \mathrm{~cm}$ (at $1 \mathrm{~L} / \mathrm{min}$ ) or $2 \mathrm{~cm}($ at $3 \mathrm{~L} / \mathrm{min}$ ) from the surface of the cell media and was not moved during treatment (Figure 1 ).

\subsection{Optical Emission Spectroscopy}

Optical emission spectroscopy with a range of $250-850 \mathrm{~nm}$ was performed on the CAP jet to detect the reactive species. The spectrometer (EPP2000-HR) and detection probe were purchased from Stellar Net Inc. (Tampa, FL, USA). The probe was placed $1.5 \mathrm{~cm}$ away from the tip of the scalpel, perpendicular to the plasma beam. The integration time was set to $100 \mathrm{~ms}$. 
A.

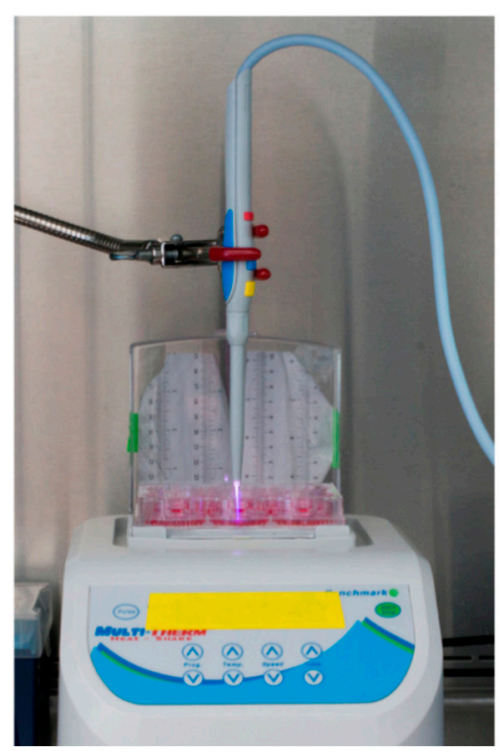

B.

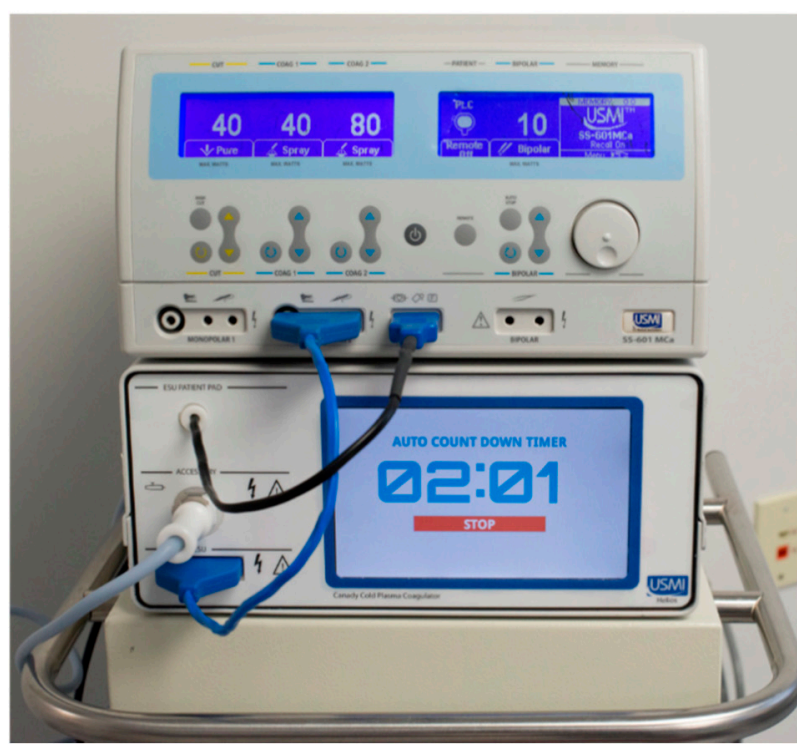

Figure 1. Solid tumor treatment with cold atmospheric plasma. (A) Cells cultured in a 12-well plate, treated using a Canady Helios Plasma Scalpel (USMI, Takoma Park, MD, USA) at 3 L/min (B) Cold atmospheric plasma (CAP) generator device; USMI SS-601 MCa (top) connected to a USMI Cold Plasma Conversion Unit (bottom).

\subsection{Cell Culture}

BxPC-3 pancreatic adenocarcinoma and 769-P renal adenocarcinoma were purchased from ATCC (Manassas, VA, USA). OE33 esophageal adenocarcinoma was purchased from Sigma-Aldrich (St. Louis, MO, USA). HCT-116 colorectal carcinoma and SK-OV-3 ovarian adenocarcinoma were generously donated by Professor Keidar's lab at The George Washington University. All cell lines were maintained with the required culture media according to the supplier protocol. When cells reached approximately $80 \%$ confluence, they were seeded at a concentration of $5 \times 10^{3}$ or $10^{5}$ cells/well into 96 -well or 12-well plates (USA Scientific, Ocala, FL, USA), respectively, for cell viability assays. For BxPC-3, $1 \times 10^{4}$ cells were required for the 96-well assay.

\subsection{Cell Viability Assay}

Thiazolyl blue tetrazolium bromide (MTT) assay was performed on the cells $48 \mathrm{~h}$ after plasma treatment following the manufacturer's protocol. Briefly, cells were incubated with MTT at a concentration of $0.5 \mathrm{mg} / \mathrm{mL} 48 \mathrm{~h}$ post treatment for $3 \mathrm{~h}$ in a $37^{\circ} \mathrm{C}$ and $5 \% \mathrm{CO}_{2}$ humidified incubator. Then, MTT solvent was added into each well to dissolve the formazan crystals. All the MTT assay reagents were purchased from Sigma-Aldrich (St. Louis, MO, USA). The absorbance of the dissolved compound was measured by BioTek Synergy HTX (Winooski, VT, USA) microplate reader at $570 \mathrm{~nm}$. Cell viability assay data has been included as supplementary material.

\subsection{Statistics}

All viability assays were repeated at least 3 times with 2 replicates each. Data was plotted by Microsoft Excel 2016 as the mean \pm standard error of the mean. A student $t$-test or a one-way analysis of variance (ANOVA) was used to check statistical significance where applicable. The differences were considered statistically significant for ${ }^{*} p \leq 0.05$. 


\section{Results}

\section{Reduction of Cell Viability by CAP in Malignant Solid Tumor Cell Lines}

To determine the effective plasma dose required to significantly reduce cell viability two flow rates were chosen; $1 \mathrm{~L} / \mathrm{min}$ and $3 \mathrm{~L} / \mathrm{min}$ of helium. Helium was used as the carrier gas because the breakdown voltage of helium is significantly lower than nitrogen [33]. In addition, the low excitation energy level of argon metastables (11.7 and $11.5 \mathrm{eV})$ in comparison with helium (20.6 and $19.8 \mathrm{eV}) \mathrm{does}$ not allow an efficient Penning ionization to sustain the discharge [34]. Based on initial testing, 1-5 min with 40-80 power, and 30-120 s with 20-40 power, were chosen as an effective range for $3 \mathrm{~L} / \mathrm{min}$ and $1 \mathrm{~L} / \mathrm{min}$, respectively. The power settings of $20 \mathrm{P}, 40 \mathrm{P}, 60 \mathrm{P}$, and $80 \mathrm{P}$ used in this study are $5 \mathrm{~W}$, $8 \mathrm{~W}, 11 \mathrm{~W}$, and $15.7 \mathrm{~W}$ at $3 \mathrm{~L} / \mathrm{min}$. At $1 \mathrm{~L} / \mathrm{min}$ of $20 \mathrm{P}$ and $40 \mathrm{P}$, the power settings are $5 \mathrm{~W}$ and $6 \mathrm{~W}$ respectively. The detailed power measurement of our CAP device was conducted and reported in another paper which is currently under review [35]. The spectrum of the CAP jet is shown in Figure 2. The most intense peaks and bands of plasma between 250 and $850 \mathrm{~nm}$ were referenced [36] and labeled in the figure. The main species observed were: $\mathrm{OH}\left(\mathrm{A}^{2} \Sigma^{+}-\mathrm{X}^{2} \Pi^{+}\right)$at $309 \mathrm{~nm}, \mathrm{~N}_{2}\left(\mathrm{C}^{3} \Pi_{\mathrm{u}}-\mathrm{B}^{3} \Pi_{\mathrm{g}}\right)$ second positive system (SPS) at 337 and $357 \mathrm{~nm} ; \mathrm{N}_{2}{ }^{+}\left(\mathrm{B}^{2} \sum_{\mathrm{u}}{ }^{+}-\mathrm{X}^{2} \sum_{\mathrm{g}}{ }^{+}\right)$first negative system (FNS) at 391 and $427 \mathrm{~nm}$; He at $667 \mathrm{~nm}$; and $\mathrm{O}^{\mathrm{I}}$ at $777 \mathrm{~nm}$. The cold plasma jet is a complicated environment that combines the comprehensive effect of a variety of ions and neutrals. These reactive oxygen and nitrogen species are playing essential roles in cellular responses to the CAP treatment $[37,38]$.

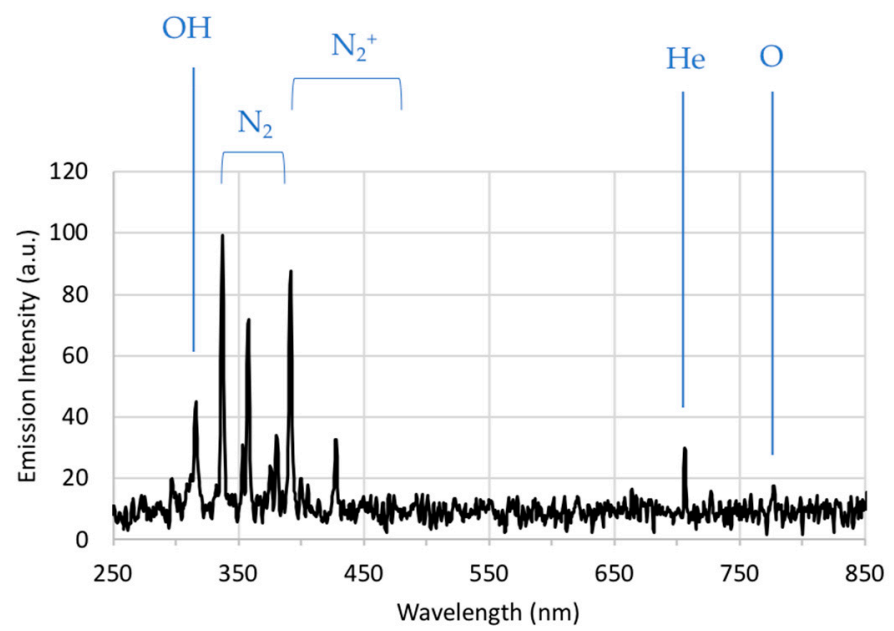

Figure 2. The spectrum of CAP generated by the USMI Cold Plasma Conversion Unit and Canady Helios Cold Plasma Scalpel. Data shown are in the optical emission spectroscopy within a range of 250-850 nm, measured $1.5 \mathrm{~cm}$ from the tip of the scalpel. Main species include $\mathrm{OH}(309 \mathrm{~nm}), \mathrm{N}_{2}$ (337 and $357 \mathrm{~nm}), \mathrm{N}_{2}{ }^{+}$(391 and $\left.427 \mathrm{~nm}\right), \mathrm{He}(667 \mathrm{~nm})$, and $\mathrm{O}(777 \mathrm{~nm})$.

MTT assays were used to determine the dose of CAP needed to significantly reduce cell viability. MTT assays were performed on CAP-treated cancer cell lines $48 \mathrm{~h}$ post treatment. The viability of the treated cells was normalized to an untreated (control) group. The viability of 769-P renal adenocarcinoma cells was dose-dependent and significantly reduced at all time and power combinations tested (Figure 3). Helium flow alone (0 W) did not significantly impact cell viability (Figure 3A). At the highest doses, using $3 \mathrm{~L} / \mathrm{min}$, viability was reduced to $4.9 \%(p<0.001)$ while viability at $20 \mathrm{P}$ for $120 \mathrm{~s}$ was $<1 \%(p<0.001)$ for $1 \mathrm{~L} / \mathrm{min}$. Increasing the power to $40 \mathrm{P}$ did not result in a further reduction ( $p=0.65$ ) (Figure $3 \mathrm{~B})$. CAP was equally as effective in reducing viability in HCT-116 colorectal carcinoma cells. At $3 \mathrm{~L} / \mathrm{min}$, viability was $76 \%$ at $40 \mathrm{P}$ for $1 \mathrm{~min}(p<0.01)$ and this decreased to $3.6 \%$ at the highest dose of $80 \mathrm{P}$ for $5 \mathrm{~min}(p<0.001)$ (Figure $4 \mathrm{~A})$. The decrease in viability when using $1 \mathrm{~L} / \mathrm{min}$ required a lower dose. Initially, at $20 \mathrm{P}$ for $30 \mathrm{~s}$ and $60 \mathrm{~s}$, viability was 
reduced to $27 \%(p<0.001)$ and $21 \%(p<0.01)$, respectively (Figure $4 \mathrm{~B})$. However, beginning at $20 \mathrm{P}$ for $90 \mathrm{~s}$ viability was reduced to $5.0 \%(p<0.001)$ which only slightly decreased with a higher dose, with the highest dose resulting in $2.6 \%$ viability $(p<0.001)$. CAP also had a clear dose-dependent effect on the reduction of viability in the ovarian adenocarcinoma cell line; SK-OV-3. At the lowest dose, using $3 \mathrm{~L} / \mathrm{min}$, viability was only reduced to $87 \%(p<0.001)$, which decreased to $17 \%(p<0.001)$ at $80 \mathrm{P}$ for $5 \mathrm{~min}$ (Figure 5A). Similar results were found with a lower flow rate (Figure 5B). $20 \mathrm{P}$ for $30 \mathrm{~s}$ resulted in $77 \%$ viability $(p<0.001)$, which decreased to $4 \%$ viability $(p<0.0001)$ at $40 \mathrm{P}$ for $120 \mathrm{~s}$. BxPC-3 (pancreatic adenocarcinoma) required a higher dose to effectively reduce viability (Figure 6A). At $60 \mathrm{P}$ for $5 \mathrm{~min}$ and $80 \mathrm{P}$ for $5 \mathrm{~min}$, viability was reduced to $14 \%(p<0.0001)$ and $4 \%(p<0.0001)$, respectively. The low flow rate treatment showed a similar pattern requiring a higher dose to reduce viability. At $40 \mathrm{P}$ for $90 \mathrm{~s}$ and $40 \mathrm{P}$ for $120 \mathrm{~s}$ the viability was reduced to $5 \%(p<0.0001)$ and $1 \%$ $(p<0.0001)$, respectively (Figure 6B). The esophageal adenocarcinoma cell line, OE33, also required a higher dose to decrease viability below $20 \%$. Using the high flow rate at $80 \mathrm{P}$ for 5 min viability was reduced to $16 \%(p<0.001)$ (Figure $7 \mathrm{~A})$. At $1 \mathrm{~L} / \mathrm{min}$ and $40 \mathrm{P}$ for $120 \mathrm{~s}$ viability was reduced to $15 \%$ $(p<0.0001)$ (Figure 7B). Taken together, this data demonstrates that CAP reduced cell viability in a time- and power-dependent manner in all cell lines tested.

A. $\quad 1.4$

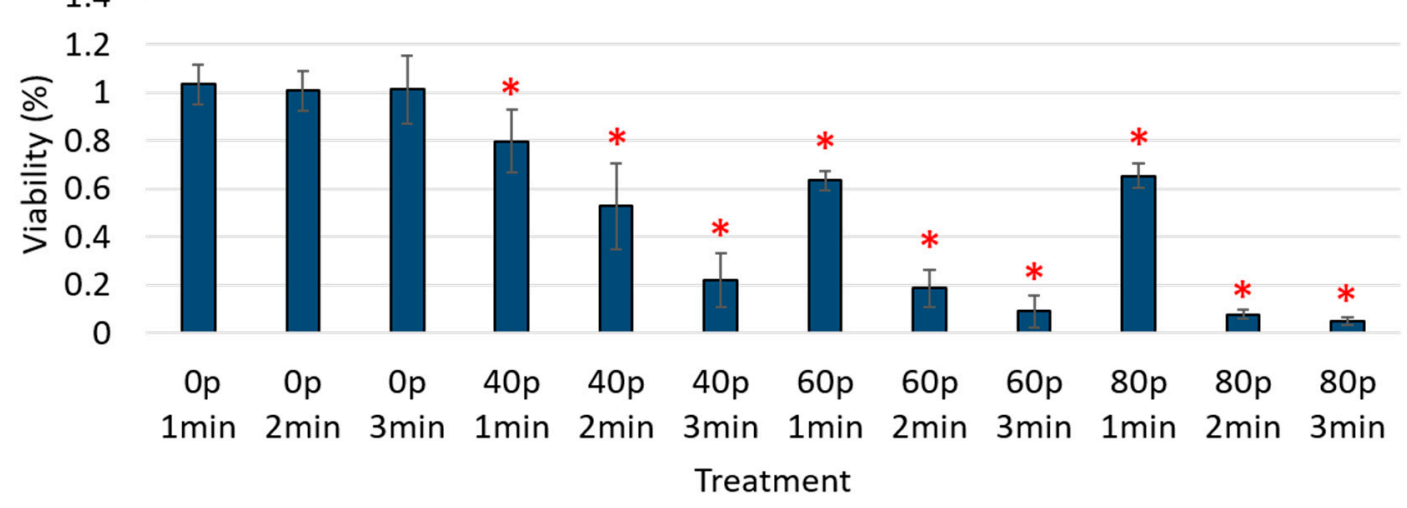

B.

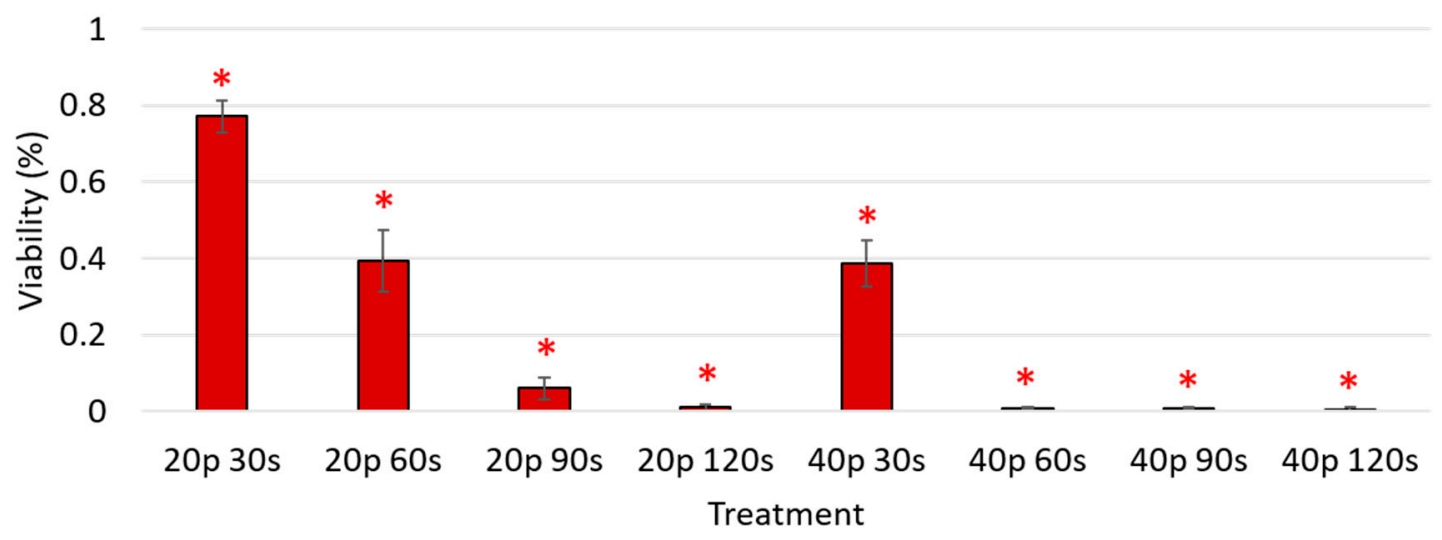

Figure 3. The reduction of viability of 769-P (renal adenocarcinoma) following CAP treatment. (A) 769-P cells were cultured in 12-well plates and treated with CAP at $3 \mathrm{~L} / \mathrm{min}$; (B) 769-P cells were cultured in 96-well plates and treated with CAP at $1 \mathrm{~L} / \mathrm{min}$. CAP treatment of 769-P significantly reduces viability at all doses tested, at both $3 \mathrm{~L} / \mathrm{min}$ and $1 \mathrm{~L} / \mathrm{min} .{ }^{*} p \leq 0.05$. 


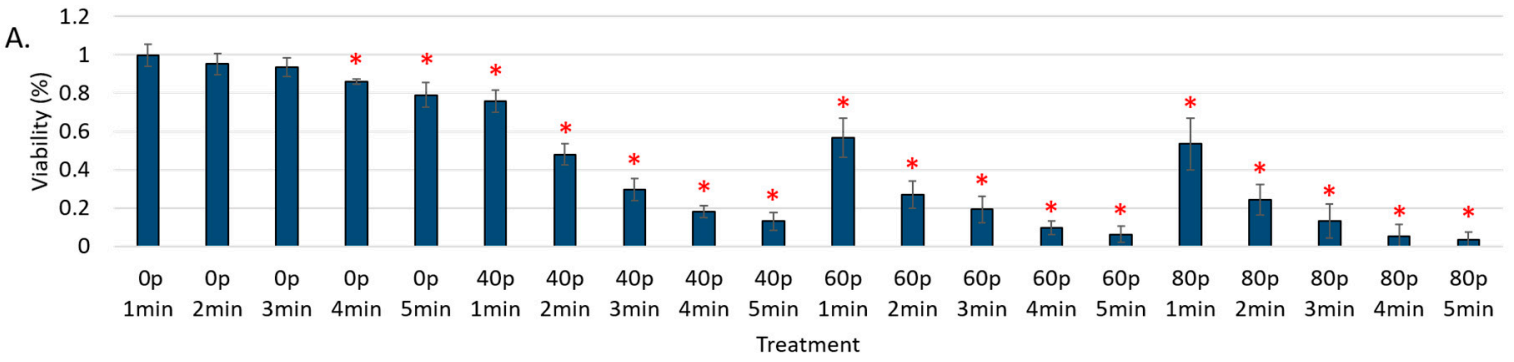

B. 1

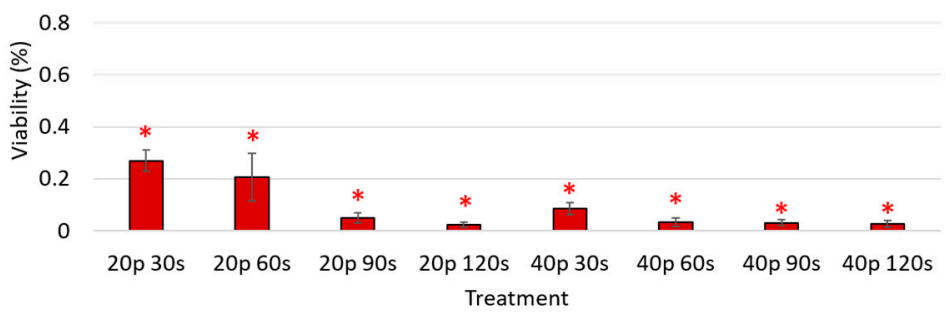

Figure 4. The reduction of the viability of HCT-116 (colorectal carcinoma) following CAP treatment. (A) HCT-116 cells were cultured in 12-well plates and treated with CAP at $3 \mathrm{~L} / \mathrm{min}$; (B) HCT-116 cells were cultured in 96-well plates and treated with CAP at $1 \mathrm{~L} / \mathrm{min}$. CAP treatment of HCT-116 significantly reduces viability at all doses tested, at both $3 \mathrm{~L} / \mathrm{min}$ and $1 \mathrm{~L} / \mathrm{min} .{ }^{*} p \leq 0.05$.
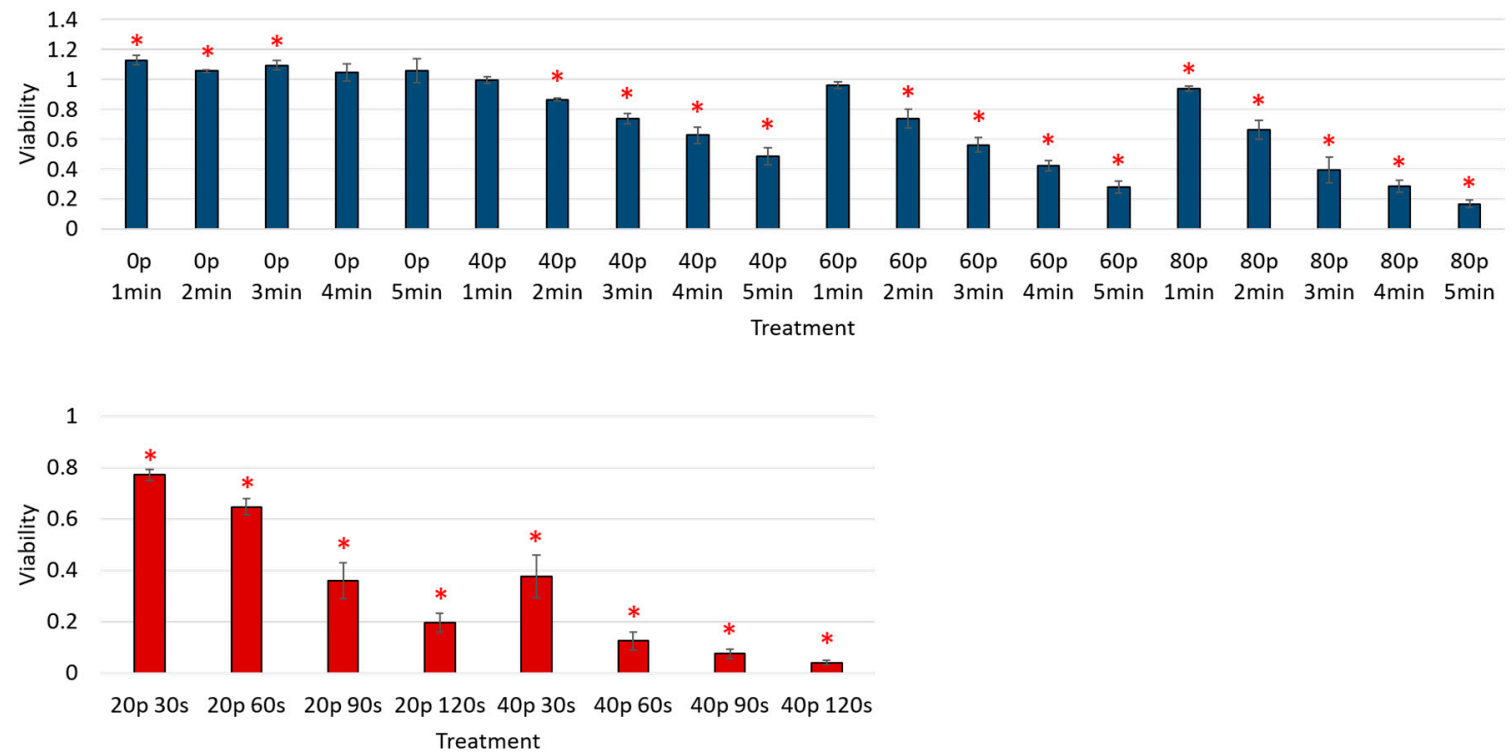

Figure 5. The reduction of the viability of SK-OV-3 (ovarian adenocarcinoma) following CAP treatment. (top) SK-OV-3 cells were cultured in 12-well plates and treated with CAP at $3 \mathrm{~L} / \mathrm{min}$; (bottom) SK-OV-3 cells were cultured in 96-well plates and treated with CAP at $1 \mathrm{~L} / \mathrm{min}$. CAP treatment of SK-OV-3 significantly reduces viability at nearly all doses tested using $3 \mathrm{~L} / \mathrm{min}$ (Figure $4 \mathrm{~A}$ ) and at all doses using $1 \mathrm{~L} / \mathrm{min}$ flow rate (Figure $4 \mathrm{~B}$ ). ${ }^{*} p \leq 0.05$. 

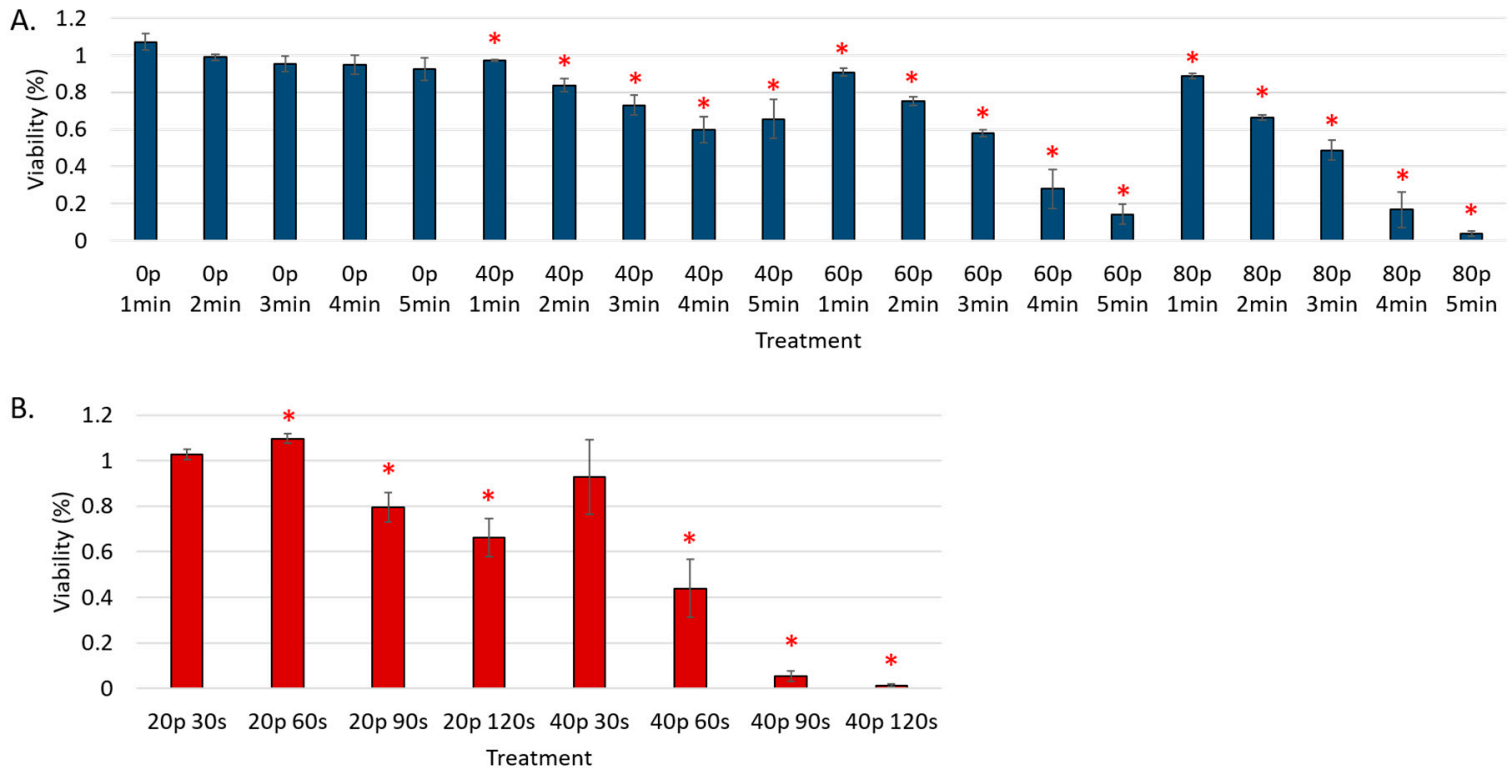

Figure 6. The reduction of the viability of BxPC-3 (pancreatic adenocarcinoma) following CAP treatment. (A) BxPC-3 cells were cultured in 12-well plates and treated with CAP at $3 \mathrm{~L} / \mathrm{min}$; (B) BxPC-3 cells were cultured in 96-well plates and treated with CAP at $1 \mathrm{~L} / \mathrm{min}$. CAP treatment of BxPC-3 significantly reduces viability at all doses tested using $3 \mathrm{~L} / \mathrm{min}$ (Figure $4 \mathrm{~A}$ ) and at nearly all doses using $1 \mathrm{~L} / \mathrm{min}$ flow rate (Figure $4 \mathrm{~B}$ ). ${ }^{*} p \leq 0.05$.
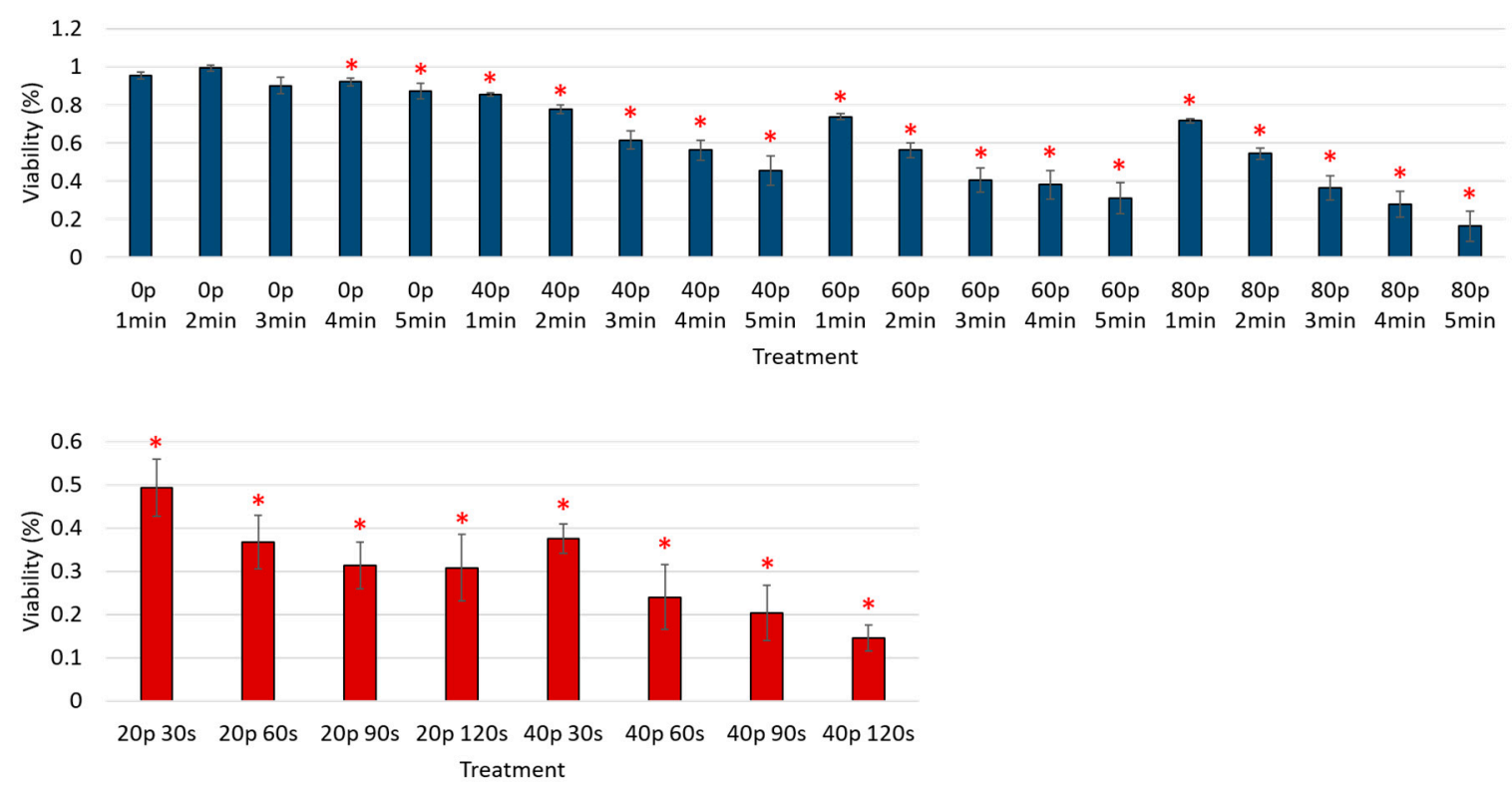

Figure 7. The reduction of the viability of OE33 (esophageal adenocarcinoma) following CAP treatment. (top) OE33 cells were cultured in 12-well plates and treated with CAP at $3 \mathrm{~L} / \mathrm{min}$; (bottom) OE33 cells were cultured in 96-well plates and treated with CAP at $1 \mathrm{~L} / \mathrm{min}$. CAP treatment of OE33 significantly reduces viability at all doses tested, at both $3 \mathrm{~L} / \mathrm{min}$ and $1 \mathrm{~L} / \mathrm{min} .{ }^{*} p \leq 0.05$.

\section{Discussion}

This study is the first effort to describe the dose-dependent reduction of viability, as a combination of treatment time and power settings, on multiple malignant solid tumor cell lines using the USMI Cold Plasma Conversion Unit and Canady Helios Cold Plasma Scalpel. This CAP does not induce 
any damage on normal tissue, which is described in detail in a separate paper [39]. CAP treatment consistently resulted in a dose-dependent reduction in viability on all solid tumor cell lines tested. While the lowest effective dose varied from cell line to cell line, in each case an 80-99\% reduction in viability was achievable $48 \mathrm{~h}$ after CAP treatment. 769-P and HCT-116 required a lower dose of plasma while SK-OV-3, BxPC-3, and OE33 required a relatively higher dose. In all cell lines tested, helium treatment alone $(0 \mathrm{P})$ showed no decrease in viability, indicating that the observed effects are due to CAP. While in several of the cell lines $1 \mathrm{~L} / \mathrm{min}$ flow rate resulted in a lower viability at a lower dose, this cannot be directly compared with the $3 \mathrm{~L} / \mathrm{min}$ results. This is because the treatment conditions, including well size, beam length, media volume, and cell number, are different between these two assays, and Yan et al. demonstrated that those conditions can alter the effect of CAP on cell viability $[17,20]$. $\mathrm{Xu}$ et al. have suggested a formula to compare plasma dose among treatment conditions within one cell type and this may be necessary to compare future results [40].

Ma et al. demonstrated that the effectiveness of non-thermal plasma treatment was partially dependent on p53 expression [19]. The viability of cancer cells lacking p53 was significantly reduced by non-thermal plasma treatment while $\mathrm{p} 53^{+}$cells were less affected. It is thought that this is due to the role of p53 in protecting the cell from reactive oxygen species [41]. However, based on the established literature, the cell lines tested here, except for SK-OV-3, have been shown to be positive for p53 (Table 1). Ma et al. also used HCT-116 and surprisingly found only a slight reduction in viability whereas we found that viability was reduced to as low as $3.6 \%$ (Figure $4 \mathrm{~A}$ ). This is likely due to differences in plasma generation, flow rate, and assay timing. The cell lines tested here also include both wild-type (WT) and mutant p53 (Table 1). Despite positive p53 expression, or status, the viability of these cell types was significantly affected by CAP treatment. However, the cell lines with wild-type p53 (769-P/Figure 3, HCT-116/Figure 4) tended to require a lower dose of CAP to reduce viability compared to those with mutant p53 (BxPC-3/Figure 6, OE33/Figure 7).

Table 1. Status and expression of p53 in all cell types tested; wild-type (WT) and mutant (MUT).

\begin{tabular}{ccccc}
\hline Cell Name & Cell Type & p53 Status & P53 Expression & Reference \\
\hline 769-P & Renal adenocarcinoma & WT & Positive & {$[42-45]$} \\
HCT-116 & Colorectal carcinoma & WT & Positive & {$[19,46]$} \\
SK-OV-3 & Ovarian adenocarcinoma & MUT/NULL & Negative & {$[45-48]$} \\
BxPC-3 & Pancreatic adenocarcinoma & MUT & Positive & {$[49-51]$} \\
OE33 & Esophageal adenocarcinoma & MUT & Positive & {$[45,52]$} \\
\hline
\end{tabular}

Further experiments will investigate the effect of CAP on additional cancerous cell lines as well as normal tissues to demonstrate the safety of our cold plasma device. The potential of CAP and chemotherapy combined therapies has been reported repeatedly [53-55]. For cell lines that require a higher dose of CAP to effectively reduce viability, that dose may be reduced with the addition of chemotherapy drugs. Lee et al. demonstrated that CAP can overcome drug resistance in breast cancer [56] and a similar combination therapy may also further reduce the viability of our cell lines. Future experiments will also include preclinical murine models to determine the efficacy of CAP on tumor reduction and prevention of recurrence. Tumors would be treated directly with CAP and tumor size and survival would be measured. To determine the effect of CAP in preventing tumor recurrence; the tumor would be surgically removed and the resulting margins would be treated with CAP. These experiments would match the approach taken in a surgical setting and could lead to improved patient outcomes.

\section{Conclusions}

This study is the first effort to describe the dose-dependent reduction of viability on multiple malignant solid tumor cell lines using the USMI Cold Plasma Conversion Unit and Canady Helios Cold Plasma Scalpel. The impact of cold plasma on the reduction of viability was consistently 
dose-dependent and, in each case, an 80-99\% reduction in viability was achievable $48 \mathrm{~h}$ after CAP treatment. These data demonstrate that the dose required to reduce viability was variable between cell lines; therefore, it is important to select the appropriate CAP dose necessary for treating a specific cancer cell type. This study will provide a cell line-specific dose estimation for future preclinical and clinical studies.

Supplementary Materials: Supplementary Materials are available online at http://www.mdpi.com/2571-6182/ $1 / 1 / 16 /$ s1.

Author Contributions: Conceptualization, W.R., X.C., G.B., B.T., M.K. and J.C.; Data curation, W.R., X.C., L.L. and T.Z.; Formal analysis, W.R., X.C.; Funding acquisition, J.C.; Investigation, W.R., X.C. and L.L.; Methodology, W.R., X.C., M.K. and J.C.; Project administration, W.R. and X.C.; Software, W.R., X.C. and T.Z.; Supervision, M.K. and J.C.; Validation, W.R. and X.C.; Writing—original draft, W.R. and X.C.; Writing—review \& editing, W.R., X.C., L.L., T.Z., G.B., B.T., M.K. and J.C.

Acknowledgments: The authors would like to thank the engineering team at Plasma Medicine Life Sciences for technical support of the plasma unit. This research was funded by US Medical Innovations.

Conflicts of Interest: The authors declare no conflict of interest.

\section{References}

1. Turhal, N. Two cases of advanced renal cell cancer with prolonged survival of 8 and 12 years. Jpn. J. Clin. Oncol. 2002, 32, 152-153. [CrossRef] [PubMed]

2. Dabestani, S.; Beisland, C.; Stewart, G.D.; Bensalah, K.; Gudmundsson, E.; Lam, T.B.; Gietzmann, W.; Zakikhani, P.; Marconi, L.; Fernandez-Pello, S.; et al. Long-term outcomes of follow-up for initially localised clear cell renal cell carcinoma: Recur database analysis. Eur. Urol. Focus 2018. [CrossRef] [PubMed]

3. Wille-Jorgensen, P.; Syk, I.; Smedh, K.; Laurberg, S.; Nielsen, D.T.; Petersen, S.H.; Renehan, A.G.; Horvath-Puho, E.; Pahlman, L.; Sorensen, H.T.; et al. Effect of more vs less frequent follow-up testing on overall and colorectal cancer-specific mortality in patients with stage ii or iii colorectal cancer: The colofol randomized clinical trial. JAMA 2018, 319, 2095-2103. [CrossRef] [PubMed]

4. Benzel, J.; Fendrich, V. Chemoprevention and treatment of pancreatic cancer: Update and review of the literature. Digestion 2018, 97, 275-287. [CrossRef] [PubMed]

5. Nakayama, Y.; Sugimoto, M.; Gotohda, N.; Konishi, M.; Takahashi, S. Efficacy of completion pancreatectomy for recurrence of adenocarcinoma in the remnant pancreas. J. Surg. Res. 2018, 221, 15-23. [CrossRef] [PubMed]

6. Conroy, T.; Desseigne, F.; Ychou, M.; Bouche, O.; Guimbaud, R.; Becouarn, Y.; Adenis, A.; Raoul, J.L.; Gourgou-Bourgade, S.; de la Fouchardiere, C.; et al. Folfirinox versus gemcitabine for metastatic pancreatic cancer. N. Engl. J. Med. 2011, 364, 1817-1825. [CrossRef] [PubMed]

7. Torre, L.A.; Trabert, B.; DeSantis, C.E.; Miller, K.D.; Samimi, G.; Runowicz, C.D.; Gaudet, M.M.; Jemal, A.; Siegel, R.L. Ovarian cancer statistics, 2018. CA Cancer J. Clin. 2018, 68. [CrossRef] [PubMed]

8. Hou, M.M.; Chen, Y.; Wu, Y.K.; Xi, M.R. Pathological characteristics and prognosis of 664 patients with epithelial ovarian cancer: A retrospective analysis. J. Sichuan Univ. Med. Sci. Ed. 2014, 45, 859-862.

9. Visser, E.; Edholm, D.; Smithers, B.M.; Thomson, I.G.; Burmeister, B.H.; Walpole, E.T.; Gotley, D.C.; Joubert, W.L.; Atkinson, V.; Mai, T.; et al. Neoadjuvant chemotherapy or chemoradiotherapy for adenocarcinoma of the esophagus. J. Surg. Oncol. 2018. [CrossRef] [PubMed]

10. Xi, M.; Yang, Y.; Zhang, L.; Yang, H.; Merrell, K.W.; Hallemeier, C.L.; Shen, R.K.; Haddock, M.G.; Hofstetter, W.L.; Maru, D.M.; et al. Multi-institutional analysis of recurrence and survival after neoadjuvant chemoradiotherapy of esophageal cancer: Impact of histology on recurrence patterns and outcomes. Ann. Surg. 2018. [CrossRef] [PubMed]

11. Arora, V. Cold Atmospheric Plasma (CAP) in dentistry. Dentistry 2013, 4. [CrossRef]

12. Niemira, B.A.; Boyd, G.; Sites, J. Cold plasma rapid decontamination of food contact surfaces contaminated with salmonella biofilms. J. Food Sci. 2014, 79, M917-M922. [CrossRef] [PubMed]

13. Schmidt, A.; Woedtke, T.V.; Stenzel, J.; Lindner, T.; Polei, S.; Vollmar, B.; Bekeschus, S. One year follow-up risk assessment in skh-1 mice and wounds treated with an argon plasma jet. Int. J. Mol. Sci. 2017, 18, 868. [CrossRef] [PubMed] 
14. Shahbazi Rad, Z.; Abbasi Davani, F. Non-thermal atmospheric pressure dielectric barrier discharge plasma source construction and investigation on the effect of grid on wound healing application. Clin. Plasma Med. 2016, 4, 56-64. [CrossRef]

15. Volotskova, O.; Dubrovsky, L.; Keidar, M.; Bukrinsky, M. Cold atmospheric plasma inhibits hiv-1 replication in macrophages by targeting both the virus and the cells. PLoS ONE 2016, 11, e0165322. [CrossRef] [PubMed]

16. Keidar, M. Plasma for cancer treatment. Plasma Sources Sci. Technol. 2015, 24, 033001. [CrossRef]

17. Yan, D.; Talbot, A.; Nourmohammadi, N.; Cheng, X.; Canady, J.; Sherman, J.; Keidar, M. Principles of using cold atmospheric plasma stimulated media for cancer treatment. Sci. Rep. 2015, 5, 18339. [CrossRef] [PubMed]

18. Naciri, M.; Dowling, D.; Al-Rubeai, M. Differential sensitivity of mammalian cell lines to non-thermal atmospheric plasma. Plasma Process. Polym. 2014, 11, 391-400. [CrossRef]

19. Ma, Y.; Ha, C.S.; Hwang, S.W.; Lee, H.J.; Kim, G.C.; Lee, K.W.; Song, K. Non-thermal atmospheric pressure plasma preferentially induces apoptosis in p53-mutated cancer cells by activating ros stress-response pathways. PLoS ONE 2014, 9, e91947. [CrossRef] [PubMed]

20. Yan, D.; Sherman, J.H.; Canady, J.; Trink, B.; Keidar, M. The cellular ros-scavenging function, a key factor determining the specific vulnerability of cancer cells to cold atmospheric plasma in vitro. arXiv 2017, arXiv:1711.09015.

21. Lee, H.J.; Shon, C.H.; Kim, Y.S.; Kim, S.; Kim, G.C.; Kong, M.G. Degradation of adhesion molecules of g361 melanoma cells by a non-thermal atmospheric pressure microplasma. New J. Phys. 2009, 11, 115026. [CrossRef]

22. Schmidt, A.; Bekeschus, S.; von Woedtke, T.; Hasse, S. Cell migration and adhesion of a human melanoma cell line is decreased by cold plasma treatment. Clin. Plasma Med. 2015, 3, 24-31. [CrossRef]

23. Shi, X.-M.; Zhang, G.-J.; Chang, Z.-S.; Wu, X.-L.; Liao, W.-L.; Li, N. Viability reduction of melanoma cells by plasma jet via inducing $\mathrm{g} 1 / \mathrm{s}$ and $\mathrm{g} 2 / \mathrm{m}$ cell cycle arrest and cell apoptosis. IEEE Trans. Plasma Sci. 2014, 42, 1640-1647. [CrossRef]

24. Chang, J.W.; Kang, S.U.; Shin, Y.S.; Kim, K.I.; Seo, S.J.; Yang, S.S.; Lee, J.S.; Moon, E.; Baek, S.J.; Lee, K.; et al. Non-thermal atmospheric pressure plasma induces apoptosis in oral cavity squamous cell carcinoma: Involvement of DNA-damage-triggering sub-g(1) arrest via the atm/p53 pathway. Arch. Biochem. Biophys. 2014, 545, 133-140. [CrossRef] [PubMed]

25. Gherardi, M.; Turrini, E.; Laurita, R.; De Gianni, E.; Ferruzzi, L.; Liguori, A.; Stancampiano, A.; Colombo, V.; Fimognari, C. Atmospheric non-equilibrium plasma promotes cell death and cell-cycle arrest in a lymphoma cell line. Plasma Process. Polym. 2015, 12, 1354-1363. [CrossRef]

26. Adachi, T.; Tanaka, H.; Nonomura, S.; Hara, H.; Kondo, S.; Hori, M. Plasma-activated medium induces a549 cell injury via a spiral apoptotic cascade involving the mitochondrial-nuclear network. Free Radic. Biol. Med. 2015, 79, 28-44. [CrossRef] [PubMed]

27. Ahn, H.J.; Kim, K.I.; Kim, G.; Moon, E.; Yang, S.S.; Lee, J.S. Atmospheric-pressure plasma jet induces apoptosis involving mitochondria via generation of free radicals. PLoS ONE 2011, 6, e28154. [CrossRef] [PubMed]

28. Kim, S.J.; Chung, T.H.; Bae, S.H.; Leem, S.H. Induction of apoptosis in human breast cancer cells by a pulsed atmospheric pressure plasma jet. Appl. Phys. Lett. 2010, 97, 023702. [CrossRef]

29. Keidar, M.; Walk, R.; Shashurin, A.; Srinivasan, P.; Sandler, A.; Dasgupta, S.; Ravi, R.; Guerrero-Preston, R.; Trink, B. Cold plasma selectivity and the possibility of a paradigm shift in cancer therapy. Br. J. Cancer 2011, 105, 1295-1301. [CrossRef] [PubMed]

30. Nuccitelli, R.; Chen, X.; Pakhomov, A.G.; Baldwin, W.H.; Sheikh, S.; Pomicter, J.L.; Ren, W.; Osgood, C.; Swanson, R.J.; Kolb, J.F.; et al. A new pulsed electric field therapy for melanoma disrupts the tumor's blood supply and causes complete remission without recurrence. Int. J. Cancer 2009, 125, 438-445. [CrossRef] [PubMed]

31. Chung, W.H. Mechanisms of a novel anticancer therapeutic strategy involving atmospheric pressure plasma-mediated apoptosis and DNA strand break formation. Arch. Pharm. Res. 2016, 39, 1-9. [CrossRef] [PubMed]

32. Canady, J.; Shashurin, A.; Keidar, M.; Zhuang, T. Integrated Cold Plasma and High Frequency Plasma Electrosurgical System and Method. U.S. Patent No. 9,999,462, 19 June 2018. 
33. Okazaki, S.; Kogoma, M.; Uehara, M.; Kimura, Y. Appearance of stable glow discharge in air, argon, oxygen and nitrogen at atmospheric pressure using a $50 \mathrm{hz}$ source. J. Phys. D 1993, 26, 889-892. [CrossRef]

34. Sublet, A.; Ding, C.; Dorier, J.L.; Hollenstein, C.; Fayet, P.; Coursimault, F. Atmospheric and sub-atmospheric dielectric barrier discharges in helium and nitrogen. Plasma Sources Sci. Technol. 2006, 15, 627-634. [CrossRef]

35. Cheng, X.; Rowe, W.J.; Ly, L.; Shashurin, A.; Zhuang, T.; Wigh, S.; Basadonna, G.; Trink, B.; Keidar, M.; Canady, J. Treatment of triple-negative breast cancer cells with the canady cold plasma conversion system: Preliminary results. Plasma 2018, submitted.

36. Pearse, R.W.B.; Gaydon, A.G. The Identification of Molecular Spectra; Chapman and Hall: London, UK, 1976.

37. Liu, Z.; Xu, D.; Liu, D.; Cui, Q.; Cai, H.; Li, Q.; Chen, H.; Kong, M.G. Production of simplex rns and ros by nanosecond pulse $\mathrm{N}_{2} / \mathrm{O}_{2}$ plasma jets with homogeneous shielding gas for inducing myeloma cell apoptosis. J. Phys. D Appl. Phys. 2017, 50, 195204. [CrossRef]

38. Lunov, O.; Zablotskii, V.; Churpita, O.; Lunova, M.; Jirsa, M.; Dejneka, A.; Kubinova, S. Chemically different non-thermal plasmas target distinct cell death pathways. Sci. Rep. 2017, 7, 600. [CrossRef] [PubMed]

39. Ly, L.; Jones, S.; Shashurin, A.; Zhuang, T.; Rowe, W.; Cheng, X.; Wigh, S.; Naab, T.; Keidar, M.; Canady, J. A new cold plasma jet: Performance evaluation of cold plasma, hybrid plasma and argon plasma coagulation. Plasma 2018, submitted.

40. Xu, X.; Dai, X.; Xiang, L.; Cai, D.; Xiao, S.; Ostrikov, K. Quantitative assessment of cold atmospheric plasma anti-cancer efficacy in triple-negative breast cancers. Plasma Process. Polym. 2018, 15. [CrossRef]

41. Sablina, A.A.; Budanov, A.V.; Ilyinskaya, G.V.; Agapova, L.S.; Kravchenko, J.E.; Chumakov, P.M. The antioxidant function of the p53 tumor suppressor. Nat. Med. 2005, 11, 1306-1313. [CrossRef] [PubMed]

42. Wang, J.; Zhang, P.; Zhong, J.; Tan, M.; Ge, J.; Tao, L.; Li, Y.; Zhu, Y.; Wu, L.; Qiu, J.; et al. The platelet isoform of phosphofructokinase contributes to metabolic reprogramming and maintains cell proliferation in clear cell renal cell carcinoma. Oncotarget 2016, 7, 27142-27157. [CrossRef] [PubMed]

43. Miyazaki, J.; Ito, K.; Fujita, T.; Matsuzaki, Y.; Asano, T.; Hayakawa, M.; Asano, T.; Kawakami, Y. Progression of human renal cell carcinoma via inhibition of rhoa-rock axis by PARG1. Transl. Oncol. 2017, 10, 142-152. [CrossRef] [PubMed]

44. Mu, W.; Hu, C.; Zhang, H.; Qu, Z.; Cen, J.; Qiu, Z.; Li, C.; Ren, H.; Li, Y.; He, X.; et al. Mir-27b synergizes with anticancer drugs via p53 activation and CYP1B1 suppression. Cell Res. 2015, 25, 477-495. [CrossRef] [PubMed]

45. Bamford, S.; Dawson, E.; Forbes, S.; Clements, J.; Pettett, R.; Dogan, A.; Flanagan, A.; Teague, J.; Futreal, P.A.; Stratton, M.R.; et al. The cosmic (catalogue of somatic mutations in cancer) database and website. Br. J. Cancer 2004, 91, 355-358. [CrossRef] [PubMed]

46. O'Connor, P.M.; Jackman, J.; Bae, I.; Myers, T.G.; Fan, S.; Mutoh, M.; Scudiero, D.A.; Monks, A.; Sausville, E.A.; Weinstein, J.N.; et al. Characterization of the p53 tumor suppressor pathway in cell lines of the national cancer institute anticancer drug screen and correlations with the growth-inhibitory potency of 123 anticancer agents. Cancer Res. 1997, 57, 4285-4300. [PubMed]

47. Antoun, S.; Atallah, D.; Tahtouh, R.; Alaaeddine, N.; Moubarak, M.; Khaddage, A.; Ayoub, E.N.; Chahine, G.; Hilal, G. Different tp53 mutants in p53 overexpressed epithelial ovarian carcinoma can be associated both with altered and unaltered glycolytic and apoptotic profiles. Cancer Cell Int. 2018, 18, 14. [CrossRef] [PubMed]

48. Yaginuma, Y.; Westphal, H. Abnormal structure and expression of the p53 gene in human ovarian carcinoma cell lines. Cancer Res. 1992, 52, 4196-4199. [PubMed]

49. Chen, D.; Niu, M.; Jiao, X.; Zhang, K.; Liang, J.; Zhang, D. Inhibition of AKT2 enhances sensitivity to gemcitabine via regulating puma and NF- $\mathrm{B}$ signaling pathway in human pancreatic ductal adenocarcinoma. Int. J. Mol. Sci. 2012, 13, 1186-1208. [CrossRef] [PubMed]

50. Wang, F.; Li, H.; Yan, X.G.; Zhou, Z.W.; Yi, Z.G.; He, Z.X.; Pan, S.T.; Yang, Y.X.; Wang, Z.Z.; Zhang, X. Alisertib induces cell cycle arrest and autophagy and suppresses epithelial-to-mesenchymal transition involving $\mathrm{PI} 3 \mathrm{~K} / \mathrm{AKT} / \mathrm{mTOR}$ and sirtuin 1-mediated signaling pathways in human pancreatic cancer cells. Drug Des. Dev. Ther. 2015, 9, 575-601.

51. Ruggeri, B.; Zhang, S.Y.; Caamano, J.; DiRado, M.; Flynn, S.D.; Klein-Szanto, A.J. Human pancreatic carcinomas and cell lines reveal frequent and multiple alterations in the p53 and Rb-1 tumor-suppressor genes. Oncogene 1992, 7, 1503-1511. [PubMed] 
52. Liu, D.S.; Read, M.; Cullinane, C.; Azar, W.J.; Fennell, C.M.; Montgomery, K.G.; Haupt, S.; Haupt, Y.; Wiman, K.G.; Duong, C.P.; et al. APR-246 potently inhibits tumour growth and overcomes chemoresistance in preclinical models of oesophageal adenocarcinoma. Gut 2015, 64, 1506-1516. [CrossRef] [PubMed]

53. Brulle, L.; Vandamme, M.; Ries, D.; Martel, E.; Robert, E.; Lerondel, S.; Trichet, V.; Richard, S.; Pouvesle, J.M.; Le Pape, A. Effects of a non thermal plasma treatment alone or in combination with gemcitabine in a MIA PaCa2-luc orthotopic pancreatic carcinoma model. PLoS ONE 2012, 7, e52653. [CrossRef] [PubMed]

54. Chen, C.-Y.; Cheng, Y.-C.; Cheng, Y.-J. Synergistic effects of plasma-activated medium and chemotherapeutic drugs in cancer treatment. J. Phys. D 2018, 51, 13LT01. [CrossRef]

55. Masur, K.; von Behr, M.; Bekeschus, S.; Weltmann, K.-D.; Hackbarth, C.; Heidecke, C.-D.; von Bernstorff, W.; von Woedtke, T.; Partecke, L.I. Synergistic inhibition of tumor cell proliferation by cold plasma and gemcitabine. Plasma Process. Polym. 2015, 12, 1377-1382. [CrossRef]

56. Lee, S.; Lee, H.; Jeong, D.; Ham, J.; Park, S.; Choi, E.H.; Kim, S.J. Cold atmospheric plasma restores tamoxifen sensitivity in resistant MCF-7 breast cancer cell. Free Radic. Biol. Med. 2017, 110, 280-290. [CrossRef] [PubMed]

(C) 2018 by the authors. Licensee MDPI, Basel, Switzerland. This article is an open access article distributed under the terms and conditions of the Creative Commons Attribution (CC BY) license (http:/ / creativecommons.org/licenses/by/4.0/). 